\title{
THE ANALYSIS OF CONFLICTS REFLECTED BY MAI CHARACTERS IN "RISE OF THE GUARDIANS" MOVIE
}

\author{
Putri Rachmawati \\ putrirachmawati855@gmail.com \\ University of Kanjuruhan Malang
}

\begin{abstract}
This study focuses on the analysis of the main characters; Jack Frost, Santa Claus, the Tooth Fairy, the Easter Bunny, Pitch Black, and the Sandman's internal and external conflicts in "Rise of the Guardians" Movie. The purpose of this study is to find out type of the internal and external conflicts based on the William Kenney's theory. The study was conducted by using descriptive qualitative approach. The findings of this study; internal conflict: Jack Frost vs. Himself and the external conflict include Santa Claus vs. Yeti, Jack Frost vs. Easter Bunny, Pitch Black vs. Group of Guardians, Jack Frost vs. Group of Guardians, Jack Frost vs. Pitch Black. The problem solving of those conflict is competitive, because the Group of the Guardians pursues their own concerns at the Pitch Black's expense.
\end{abstract}

Keywords: Conflict, main character, rise of the guardians, movie

\section{INTRODUCTION}

Literature is a part of art to express the author's imaginations or ideas about something. It is an expression of aesthetic and imaginative fact of human life, because it is arranged through a great unity of concept, expression form, emotion, and language which is relates in daily life of society. Taylor (1981) states that literature like other arts, is essentially an imaginative act of the writer's imagination in selecting, ordering, and interpreting life experiences.

Rise of the Guardians is a 2012 American 3D computer-animated fantasy film based on William Joyce's The Guardians of Childhood book series and The Man in the Moon short film by Joyce and Reel FX Creative Studios. Directed by Peter Ramsey, this movie was released on November 21, 2012. Nowadays, many movies were made based from the novel. It is an American myth movie telling about a Guardian called Jack Frost. He becomes a part of American myth Guardians (Santa Claus, the Sandman, the Easter Bunny, the Tooth Fairy), who protects children happiness and dream. Nobody believes in him and make him invisible. Jack has to cooperate with the other Guardians to make everyone believe in him and protect children from the nightmare. However, the antagonist character Pitch Black was tried to make the children to stop believing in the Guardians. He wants to destroy the children happiness and dreams with nightmare. Rise of the Guardians movie is a representation of the mythical stories of Americans who have long existed. The film became one of the results of modern media in conveying cultural values of the past as a lesson, attitude, and advise for children. How the protagonist character faced their conflicts and how do they solve that? This movie has many conflicts inside the plot. We can also find many conflicts in our live or in the society. As a result, it is important to study about conflicts and how to solve those conflicts. 
Sanderson (1991) states that conflict as an opposition of interest between and among various individuals and social groups, which may or may not be overtly observable, and which may break out into open dispute of physical violence. As a human being many conflict that happen in our life or in the society. According to Napitupulu (2009) conflict is one of social processes which happened in our life involving some of people or group of people which challenge each other which has inviolacy impact. Actually conflict comes from, cooperation and competition. Conflict is not always has negative impact. With the conflict, people can get the best solution in every problem that happened in human life. In daily life, a person is confronted with many problems and obstacles. From the conflict or problem, he or she is facing some complicated situation, so he or she should choose the best solution to solve their problems according to his/her own consideration. In this thesis, the researcher use theory from William Kenney (1966) about conflict in literary work. He said that conflicts can occur in a story from inside or outside the characters. Conflict that exists inside the character's mind is called internal conflict. In contrast, conflict that exists beyond the character or it deals with the problems of the world is external conflict.

There are some reasons why the topic was chosen to be analyzed. First, the plot development of the story is the main element to decide a good movie. Plot is a logical series of events having a beginning, middle, and end, making the story more interesting and easier to understand. Second, characters also have their important functions during the development of plots and as the subjects who experience the problems and the conflicts which have roles in developing the plot of the story. This movie is expressing conflicts experience by the characters or the main characters. The conflict can be between the protagonist and another character, the antagonist between the protagonist and nature; or the protagonist and society. It can also be an internal or psychological conflict (Kenney, 1966). It is interesting to analyze the conflicts of the main character in the story. There is a close relationship between character and conflicts. They are trapped to solve their conflicts which appear internally and externally.

Then the research questions are formulated as follows:

1. What kinds of conflicts are faced by the characters in Rise of the Guardians fiction movie?

2. How do the characters solve their problems?

\section{RESEARCH METHOD}

This study used descriptive qualitative design. It presents words or sentences which give clear and detail information related to the data, and the data are in the form of description, not in the form of number. Listyani (2014) said that the sources of the data are taken from some of relevant data that support the analysis. The data to be analyzed are gathered from two sources, the primary source, and secondary source. The primary source from this research is the literary work of movie Rise of the Guardians that there are found the extrinsic and intrinsic conflicts between characters and analyzing the word, sentence, or phrase of the movie. In addition, the other source includes many appropriate documents in form of theory, Wikipedia or internet, and other references to support the analysis. The secondary source from this research is found from other 
researcher that already did a research before in the research journal, article journal, critic literature, magazine, etc.

In order to collect data, the researcher used the documentation method. Napitupulu (2009), states that documentation method is the way to take data by watching or reading the source and making the list of collected data. Besides, Setiawan (2014) states that documentation is a written or printed original paper, official or legal form of something and can be used to deliver important evidence or information. Documentation in this case is the "Rise of The Guardians" movie script. The researcher took note that it is necessary in the film with a screenplay print "Rise of the Guardian". When watching the film, the researcher marked the parts of the conversations as the subject of research and then recapitalize them into a table by doing several steps as follows:

1. Watching the movie "Rise of the Guardians" and reading all of the movie script at the same time to make the conversations compatible to each other.

2. Colleting and taking notes or writing important information such as words, sentences, and paragraphs related to the intrinsic and extrinsic conflicts between characters from the "Rise of The Guardians" movie script. According to Sudaryanto (1993), that Observation Technique is to pay good attention to the dialog but not to take apart in the dialog. After that, the researcher taking notes from the dialog.

3. Transferring the data into data table according to the components of each process.

4. Drawing some conclusion based on the analysis.

The researcher used Rise of the Guardians movie as the object of analysis and primary source of data. The researcher focused on sentences related to the topic of this research - the conflict between the characters.

According to Miles and Huberman (1994), there are three theories of qualitative design such as data reduction, data display, and data verification. Data reduction refers to the process of selecting, simplifying, abstracting and transforming the data. They argue that data collection and data analysis should overlap to allow for flexibility in data collection procedures so that the researcher remains open to new ideas.

The steps of analyzing the data are as follows:

a. Preparing

In this step, the researcher constructed the outline of the research, and book review. It was taken from the work of literature.Watching the movie "Rise of the Guardians" and reading the movie script at the same time to make the conversations compatible to each other.

b. Classifying

This step, the researcher classified the internal and external conflict into each part. Classifying every conflict experienced by the main characters in the movie using theory of conflict by Reaske (1966). Then transferring the data into data table.

c. Analyzing the internal and external conflict

Analyzing the topic and the conflict solve in the end of the story using theory from Thomas \& Killman (1970).

d. Checking the data with the expert and the source 
e. Taking conclusion

The last step, the researcher made conclusion of this study.

\title{
RESEARCH FINDING \\ 1. Internal Conflict
}

1.1 Jack Frost vs. Himself

Data A. Jack Frost vs. His loneliness (00:12:24)

Mrs. Bennett: "Jamie? Hat?[Puts a warm weather beanie on his head.] You don't want Jack Frost nipping at your nose!"

Jamie: “Who's Jack Frost? “

Mrs. Bennett: "No one, honey, it's just an expression."

Jack: "Hey!"

From the conversation found in Data A, that no one believes with Jack Frost including Jamie and Jamie's mom. He felt so lonely and frustrate. The next Jack's conflict occurred when the Man in the Moon has been selected Jack as the newest Guardian. The Group of the Guardians meets up with Jack in the North Pole, and they reveal that Jack was chosen by the Man in the Moon to become the next Guardian. Jack declines the invitation because frustrated and hurt by centuries of isolation, but Santa explaining their mission.

The resolution of the conflict is to make Jack Frost join with them the group of Guardians to protect children dreams, hope, and happiness from Pitch Black. Santa Claus makes Jack to believe that he has something special inside that is why the man in the moon chose him as a Guardian.

\section{External Conflict}

\author{
2.1 Santa Claus vs. Yeti \\ Data B. Santa vs. Yeti (00:04:45) \\ Santa: "Ah! Finally! Mm mm!" \\ Yeti: [Bursts in while shouting and breaks the glass train-plane] \\ Santa and Yeti: “Ah! Ahh!!” \\ Santa: "How many times have I told you to knock?" \\ Yeti: [answers incomprehensibly to the audience] \\ Santa: "What? The globe?"
}

From those conversation found in Data B, Santa was angry with Yeti that broke his glass train-plane. Yeti did not knock the Santa Claus's door because there is a trouble with the globe. The resolution of this conflict Santa came to the globe and seen that the Pitch Black was came and threated the children happiness and dreams with his nightmare. Then Santa and the Guardians see that the Man in the Moon was chosen the newest Guardians to help them defeat Pitch Black.

\subsection{Jack Frost vs. Easter Bunny}

Data C. Jack Frost vs. Easter Bunny (00:23:07)

Bunny: "But none of 'em believe in ya. Do they? Y'see, you're invisible, mate - it's like you don't even exist."

Tooth: "Bunny! Enough!”

Jack: "No, the kangaroo's right."

Bunny: "The- the what? What'd you call me? I'm not a kangaroo, mate." 
Jack: “Oh! And this whole time I thought you were. If you're not a kangaroo, what are you?"

Bunny: “I'm a bunny. The Easter Bunny. People believe in me."

From those conversation found in Data C, Man in the moon chooses Jack as a Guardian, but he refuses, saying it is not for him. Jack thinks that the group of Guardians did not want him, because they are all hard work and deadlines, and Jack is snowballs also fun times. He said that he is not a Guardian. Then the fights begin between Jack and Easter Bunny.

The resolution of the conflict is Santa takes Jack away and explains to him about The Man in The Moon must have known that Jack has something special in him and Santa reveals his center, which is Wonder, through the use of a nesting doll of him. Jack, still confused, doesn't know what his center could be. Santa Claus makes Jack to believe that he has something special inside that's why the man in the moon chose him as a Guardian.

\subsection{Pitch Black vs. Group of Guardians}

Bunnymund reveals there's trouble in Tooth's Palace and they have to make their way to help Tooth. On their way there, it's revealed that Pitch has sent his Nightmares to catch all the fairies and collect the teeth of the children of the world. Jack saves Baby Tooth from one of the Nightmares before they arrive inside of the Palace to find a panicking Tooth. Pitch then confronted the Guardians and after a battle between then he escapes. Jack, curious, asks why Pitch took the teeth and Tooth reveals that the teeth hold the greatest childhood memories, the reason why she collects the teeth. She also reveals that the Guardians were all somebody before they were chosen by the Man in the Moon, even Jack. Jack, surprised, asks her about his past life and about his family to which Tooth asks if he really does not remember anything and that she can not help him since Pitch has his tooth box.

Data D Pitch Black vs. Guardians (00:30:12)

Pitch: "I have to say... this is very, very exciting. The Big Four, all in one place. I'm a little starstruck. Did you like my show on the globe, North? Gotcha all

Santa: "Argh!" together, didn't I?"

Tooth: "Pitch! You have got 30 seconds to return my fairies—-"

Pitch: "Or what? You'll stick a quarter under my pillow?"

Santa: "Why are you doing this?"

Pitch: "Maybe, I want what you have. To be believed in! Maybe I'm tired of hiding under beds!"

Bunny: "Maybe that's where you belong!"

The resolution of the conflict is North plans to collect the teeth to keep the children believing in Tooth. North asked Jack to help them collect the teeth and in return they would help him get his memories back and Jack agrees to help them. The Guardians go around the world collecting teeth and making a competition of it. When Tooth tells them they were as fast at collecting teeth and leaving gift as her fairies, the guys realize that they forgot to leave a gift and have to travel back around the world to leave the gifts.

\subsection{Jack Frost vs. Group of the Guardians}


Tooth: "Where's Baby Tooth? [She gasps again, more horrified] Oh Jack, what have you done?"

Santa: "That is why you weren't here? You were with Pitch?"

Jack: “No, listen! Listen! I'm sorry! I didn't mean for this to happen!”

Bunny: "He has to go."

Jack: [turns to face Bunny] “What?"

Bunny: "We should never have trusted you! [Bunny looks heartbroken, betrayed, then shakes his head] Easter is... new beginnings, new life. Easter's about Hope. And now it's gone."

[Jack turns around, but Santa and Tooth turn away from him. Jack pulls out the wooden baby from Santa's nesting doll and drops it in the grass.]

From those conversation found in Data E, all the Guardians disappointed and did not believe with Jack. Pitch tempted Jack with his memories but also with his fears of not being believing in.

The resolution of the conflict is Jack Frost came to the Jamie house as the last believer in the world, and made him to believe in the Easter Bunny. That night Jack rushed to Jamie's house to get him, since he's the last believer in the world, Jack finds him talking to his stuffed bunny asking him (Bunnymund) to give him a sign so he knows he's real. Jamie seems to start losing hope in the Guardians until Jack makes an egg with his ice powers in his window. Getting Jamie's attention, Jack makes a bunny and makes it come to life and jump around the room. Jamie gets very excited.

\subsection{Jack Frost vs. Pitch Black}

Data F. Jack Frost vs. Pitch Black (01:01:20)

Pitch: "I thought this might happen. They never really believed in you. I was just trying to show you that. But I understand."

Jack: "You don't understand anything!"

Pitch: "No?! I do know what it's like to be cast out! To not be believed in! To long for... a family."

Pitch: "All those years in the shadows, I thought, 'No one else knows what this feels like.' But now I see I was wrong. We don't have to be alone, Jack. I believe in you and I know children will too!"”

Jack: "In me?"

Pitch: "Yes! Look at what we can do! What goes together better than cold and dark? We can make them believe! We'll give them a world where everything, everything is-

Jack: "Pitch Black?"

Pitch: "And Jack Frost too. They'll believe in both of us."

Jack: "No, they'll fear both of us. And that's not what I want. Now for the last time, leave me alone."

Pitch: "Very well. You want to be left alone? Done! But first..."

Jack: “Baby Tooth!”

Pitch: "The staff, Jack! You have a bad habit of interfering. Now hand it over, and I'll let her go."

Jack: "Alright - now let her go."

Pitch: "No. You said you wanted to be alone. So be alone!"

Pitch: "Oh!” [He throws her into a nearby crack in the ice.]

Jack: "No!" [He watches her fly away, then turns took at Pitch as he breaks thestaff in half. Jack groans in visible pain.]

[Pitch slams Jack into the side of the ice with his black sand and lets Jack drop into the same crevice as Baby Tooth. Pitch laughs as he drops the broken staff into the fissure with them, and leaves.] 
From those conversation found in Data F, Pitch is invisible to children like Jack is, but since Jack was chosen as a Guardian by man in the moon, Pitch is jealous. He asked Jack Frost to join with him to make the children believe with them, but Jack Frost did not want to do it. Jack did not want the children fear with him. Pitch hold Baby Tooth up in one hand, and said that he will let her go if Jack give his staff to him. When Jack Frost gave it to him, Pitch did not let Baby Tooth go. He tricked Jack Frost, Pitch broke Jack's staff. Finally, he dropped Jack Frost, Jack's broken staff, and Baby Tooth into crevice and leave them alone. Soon after Jack's memories called him again, making him remember that he still has his Tooth Box. Baby Tooth taught Jack how to use the Tooth Box, which revealed Jack's human past. The flashbacks showed Jack some of the fun memories he did have with his sister and also showed him the moment when he saved her from the ice. These memories made Jack realize that he always has been a Guardian and gave him the courage to fix his mistake and save the Guardians and the children of Earth from Pitch. Jack was able to fix his staff and made his way back to Pitch's lair to rescue the fairies, but found out that they couldn't fly since there were only a few lights left.

Jack noticed that the last light was Jamie and he made his way back to Burgess to recruit Jamie. That night Jack rushed to Jamie's house to get him, since he's the last believer in the world. Jamie seems to start losing hope in the Guardians until Jack makes an egg with his ice powers in his window. Getting Jamie's attention, Jack makes a bunny and makes it come to life and jump around the room. Jamie gets excited and starts jumping in his bed until the Easter bunny turns into snow, resulting in a snowflake to nip at his nose and for him to believe in Jack Frost. Jamie asked "Jack Frost?" which caused Jack to look at Jamie and wonder if Jamie believed it him. When Jamie revealed he can see and hear him, Jack gets excited about having his first believer.

\section{Problem Solving of the Movie}

The internal and external conflicts from the main characters in the movie directed by Peter Ramsey entitled Rise of the Guardians can be found from six main characters in this movie, there are Jack Frost, Santa Claus, the Tooth Fairy, the Easter Bunny, Pitch Black, and Sandman. Jack Frost is invisible, but in the end of the movie Jamie revealed he can see and hear him, Jack gets excited about having his first believer. When they hear North's sleigh, both of them rush outside. Jamie reveals that he can see Jack and the other Guardians. Easter Bunny thanks Jack for making Jamie keep his belief in him. When Pitch appears, Jack goes to fight him, causing the other Guardians to lead Jamie away. Pitch being more powerful than before, traps the Guardians and Jamie, Jamie tells Jack that he's scared. Hearing that, Jack gets a memory of the same thing his sister once said causing Jack to realize what his center is Fun.

With the help from the other Guardians, Jamie's friends start to believe again. Pitch asks them who was going to protect the Guardians if the Guardians were protecting them. Jack reassured Jamie not to be scared since the Nightmares are just bad dreams and Jamie volunteered to protect the Guardians causing his friends to join him. Pitch then sends a wave of nightmare sand their way but once Jamie says, "I do believe in you. I'm just not afraid of you!" Jamie was able to turn the nightmare sand back into Dreamsand, which helps the Guardians get their full energy back and battle Pitch. Jamie 
gets an idea on how to revive the Sandman and told his friends about it. As the battle with Pitch continued, the Nightmare King was cornered by the Guardians, but hid in the shadows and appeared behind a distracted Jack with scythe created out of nightmare sand, but before he could hurt him, the Sandman returns at the last second saving Jack from Pitch and uses his sand to give everyone good dreams and make more believers.

The Guardians and the children started celebrating and Jack hits Jamie with a snowball, which caused a friendly snowball fight. After Pitch was taken away by his own Nightmare creatures, the Guardian ceremony was performed again. Jack looked at Jamie which caused him to nod. Proud of himself and of Jamie, Jack says, "I will," making him an official Guardian. "Then congratulations, Jack Frost, for you are forevermore...a Guardian." Jack was happy. Happy to have helped defeat Pitch and to finally know who he really was: a Guardian. He turned back to watch Jamie as the sleigh careened into the morning sky. "My name is Jack Frost, and I'm a Guardian. How do I know that? Because the moon told me so, So If the moon tells you something... Believe it." At this victory, Jack accepts his place as the Guardians of Fun andresolves to protect the world's children with his new friends.

\section{DISCUSSION}

In this analysis the researcher discussed the internal and external conflict reflected by the main characters in Rise of the Guardians Movie using the theory of Conflict by William Kenney (1966). Character may face several types of outside forces. The outside forces may be another character or Man vs. man. It may be the community or man vs. society. The outside force may also be forces of nature or man vs. nature, and man vs. fate. Meanwhile, the internal conflict is the opposition between a person against him or herself, it is also known as the inner conflict.

The researcher found that there was one conflict of the internal conflict; Jack Frost vs. Himself, and five conflicts; Santa Claus vs. Yeti, Jack Frost vs. Easter Bunny, Pitch Black vs. Group of the Guardians, Jack Frost vs. Group of the Guardians, and Jack Frost vs. Pitch Black in the external conflict that faced by the main characters. The internal conflict faced by the main characters is Jack Frost vs. himself. The internal conflict for Jack Frost, as one of the main characters in this movie, his internal conflict are most from his search to found who really he was or why he was created. In the beginning he refused to be the newest Guardians, the source of Jack's anti-social behavior towards the Guardians and refusal to adhere to rules was mostly because of his frustration with the Man in the_Moon never answering his questions about who he was or why he was created, and also because no human, child or adult, was able to see him for centuries for no one had believed in him. He felt so lonely and frustrate. Then He thought that he is not qualified become a Guardian, but Santa explained their mission. It is to protect the children happiness and dreams from Pitch Black. Finally, Jack Frost found who he was and found his center was Fun.

The external conflicts in the movie entitled Rise of the Guardians can be found from the main character that is having conflict with another minor character from this movie. The external conflict dominated by Jack Frost as the one of the main characters. These are the external conflict faced by the main characters include Santa Claus vs. Yeti, Jack Frost vs. Easter Bunny, Pitch Black vs. Group of Guardians, Jack Frost vs. Group of Guardians, Jack Frost vs. Pitch Black. Based on the William Kenney (1966) 
theory it was found that the Rise of the Guardians movie dominated with the conflicts between Man vs. Man such as North vs. Yeti, Jack Frost vs. Easter Bunny, Jack Frost vs. Pitch Black, and also Man vs. Society such as Pitch Black vs. Group of Guardians, Jack Frost vs. Group of Guardians.

The external conflict faced between Santa Claus vs. Yeti occurs when Santa Claus made the glass train-plane, without knocked Yeti burst the door and broke it. Then Santa was very angry. Yeti did not knock the Santa Claus's door because there is a trouble with the globe. Santa came to the globe and seen that the Pitch Black was came and threated the children happiness and dreams with his nightmare. This conflict included in the Man vs. Man conflict. Other man vs. Man conflict was faced between Jack Frost vs. Easter Bunny the conflict occurs at the North Pole, Jack meets up with the guardians and they reveal that Jack was chosen by Man in the Moon to become the next Guardians and that Pitch has returned. Jack refused the offers. Tooth tries to explain what they do and the joy they bring to kids, but Easter Bunny think Jack does not know anything about bringing joy to the children causing a fuss between Bunny and Jack. Conflict between man vs. Society are including Pitch Black vs. Group of Guardians, and Jack Frost vs. Group of Guardians. The resolution of all the conflict that Jack realized what his center is: Fun. He finally found his center and who he could be, it is to make and bring happy and joy to all the children in the world.

Finally, based on the characteristic of the movie itself, that the movie is also the pictures and as the representatives of human real life, it seems that the reader to know what to do, how to behave, and what decision should we choose when a person encounter the conflicts in their life.

\section{Conclusion}

Rise of the Guardians Movie had so many conflicts in the story. It can be drawn that the external conflicts were dominated by Jack Frost as the one of the main characters. These are the external conflict faced by the main characters include Santa Claus vs. Yeti, Jack Frost vs. Easter Bunny, Pitch Black vs. Group of Guardians, Jack Frost vs. Group of Guardians, Jack Frost vs. Pitch Black. And the resolution of all the conflict that Jack realized what his center is: Fun. He finally found his center and who he could be, it is to make and bring happy and joy to all the children in the world.

Meanwhile, the internal conflict faced by Jack Frost vs. Himself is his internal conflict are most from his search to found who really he was or why he was created. Finally, Jack Frost found who he was and found his center. Jack realized what his center is: Fun.

Finally, based on the characteristic of the movie itself, that the movie is also the pictures and as the representatives of human real life, it seems that the reader to know what to do, how to behave, and what decision should we choose when a person encounter the conflicts in their life.

The researcher expects that the findings of this study can be the reference for the next researchers. The researchers can take the points in her study. She also suggests the researchers analyze another element in the Rise of the Guardians from other side because there are many intrinsic elements especially the values of life that can be discussed. 


\section{REFERENCES}

Bagus, I. (2013). The Analysis of Conflict in the Movie Script Avatar by James Cameron. Bali: Udayana University.

Bennett, A., \& Royle, N. (2014).An Introduction to Literature, Criticism, and Theory $3^{\text {rd }}$ Edition. London: Pearson Education Limited.

Hanifah, A. N. (2014). Calvin Weir Fields' Internal Conflict In Ruby Sparks Film. Yogyakarta: State Islamic University Sunan Kalijaga.

Jane, S. (2008). An Overview of the Thomas-Kilmann Conflict Mode Instrument (TKI).Australia: The Courageous Mosaic. Retrieved from http://An/Overview/of/the/TKI_Kilmann/Diagnostics.htm (access on October 19, 2016).

Kenney, W. (1966).How to Analyze Fiction. Ney York: Monarch Press

Kusumawati, E. (2007). An Analysis on Intrinsic Elements of Agatha Christie's "The Pale Horse”.Jakarta: State Islamic University "SyarifHidayatuallah of Jakarta.

Lawrence, J., \& Tar, U. (2013). The use of Grounded Theory Technique as a Practical Tool for Qualitative Data Collection and Analysis.Electric Journal of Business Research Methods, vol.11, 29-40.

Napitupulu, H. (2009). An Analysis of the Main Characters' Conflicts in Nathaniel Hawthorn's Novel "Scarlet Letter". Medan: University of North Sumatera.

Nazir, Moh. (1985). Metode Penelitian. Jakarta: Ghalia Indonesia.

Nisak, N. (2014). The Role of the Main Character's Psychological Conflicts to the Theme Seen in Ahmad Fuadi's "The Land of Five Towers". Tulungagung: State Islamic Institute.

Oktavia, A. V., \& Sulistyorini, H. (2013).Magwitch's Self Esteem Motivate Described in Charles Dickens's Great Expectations. Semarang: Dian Nuswantoro University Semarang.

Perrine, L. (1983). Literature: Structure, Sound, and Sense $4^{\text {th }}$ Edition. New York: Harcourt Brace Jovanovich, Inc.

Priadi, R. (2009). An Analysis of the Main Characters' Conflicts in Mitch Albom's Tuesday with Morrie. Medan: University of North Sumatera.

Reaske, C. R. (1966). How to Analyze Drama.New York: Monarch Press.

Setiawan, I. S. (2014).An Analysis on Moral Values as Seen in "Rise of the Guardians" Movie.Salatiga: States Islamic Studies Institute (STAIN). 
Waris, A., Y., \& Salombe, M. K. (2013).An Analysis the Main Characters and the Plot in the Novel of Bacharuddin Jusuf Habibie's Habibie and Ainun.e-Journal of English Language Teaching Society (ELTS), vol.1, 1-14.

Wayan, I. W. (2009). The Main Character's Conflicts in Stephenie Mayer's Novel "Twilight Saga: New Moon". Bali: Udayana Univesity.

http://riseoftheguardians.wikia.com/wiki/Rise_of_the_Guardians_(transcription)

http://en.m.wikipedia.org/wiki/Rise_of_the_Guardians 